\title{
How Does Corporate Governance Affect Bank Performance? The Mediating Role of Risk Governance
}

\author{
Paola Leone ${ }^{1}$ Carmen Gallucci $^{2} \&$ Rosalia Santulli $^{2}$ \\ ${ }^{1}$ Department of Management, University of Rome, Italy \\ ${ }^{2}$ Department of Management and Innovation Systems, University of Salerno, Italy \\ Correspondence: Rosalia Santulli, Department of Management and Innovation Systems, University of Salerno, \\ Italy. E-mail: rsantulli@unisa.it
}

Received: May 24, 2018

doi:10.5539/ijbm.v13n10p212

\author{
Accepted: July 21, $2018 \quad$ Online Published: September 21, 2018 \\ URL: https://doi.org/10.5539/ijbm.v13n10p212
}

\begin{abstract}
This paper aims to investigate how bank governance (board size, board composition, ownership structure) affects performance (ROA), by considering the mediating role of risk governance (presence of a risk committee, the number of meetings of the risk committee in one year, the risk committee size, the percentage of independent directors in the risk committee, and the presence of a chief risk officer). A sample of 31 Italian listed banks is examined over a ten-year period (2008-2017), in order to delineate the changes in corporate governance structure and to catch the effects of the current national and European regulations followed to the financial crisis. Hypotheses are tested by applying a mediation analysis according to the causal steps procedure. The main findings suggest that risk governance fully mediates the corporate governance-bank performance relationship. Specifically, we find that the board size is positively related to the presence of a risk committee and to the number of meetings. The percentage of independent directors on board is positively related to the percentage of independent directors in the risky committee and, in turn, has a positive effect on performance. Finally, the presence of institutional owners is positively related to the presence of a chief risk officer and, thus, to bank performance. Summing up, banks with wider and more heterogeneous boards of directors have better risk management-related corporate governance mechanisms and reach higher performance levels.
\end{abstract}

Keywords: bank governance, risk governance, performance, regulation

\section{Introduction}

On the wave of the recent financial crisis, the corporate governance of financial institutions has heated the policy debate and has become the focus of a swarm of academic research (e.g., Pathan \& Skully, 2010; Aebi et al., 2012; Liang et al., 2013; Pathan \& Faff, 2013; Stulz, 2016; Abou-El-Sood, 2017; Farag \& Mallin, 2017). The health of the financial sector is actually more important than other industries (Adams \& Mehran, 2003; Macey \& O'Hara, 2003) since its failure could interrupt the economic development of countries and would have costly consequences (Flannery, 1998). Because of this, banking Institutions are highly regulated compared to others. However, bank regulators and supervisors find a lot of difficulties in preventing bank failures just thorugh the laws and the ultimate responsibility lies with board of directors since they establish the strategy, choose the managers and set operational policies for ensuring bank's survival (Greuning \& Bratanovic, 2003). Therefore, in order to avoid possible failures, representing a great concern to policy makers, and in order to guarantee that banks can identify, evaluate and manage the risks to which they are exposed, it is necessary to discipline through appropriate regulations the bank governance. A bad bank governance could actually lead the market in losing confidence towards bank's ability in suitably managing its assets and liabilities and trigger, in turn, a liquidity crisis, which could translate in a systemic economic and social crisis (Cebenoyan \& Strahan, 2001; Basel Committee on banking supervision, 2006; Alexander, 2006; Garcia-Marco \& Robles-Fernandez, 2008). Recent academic studies have emphasized that, during the financial crisis of 2007/2008, a crucial role on the reduction of banks' performance was played by the weaknesses in bank governance (e.g., Diamond \& Rajan, 2009). On the same line, a recent OECD report has ncluded that the flaws in bank governance have contributed in a relevant manner to the financial crisis (Kirkpatrick, 2009). Due to that, bank governance deserves special attention and it makes interesting to examine its mechanisms, aiming to mitigate opportunistic behaviors and to reflect the needs of shareholders, creditors, and the taxpayer (Srivastav \& Hagendorff, 2016), and its effects on bank performance. 
Some previous studies have already investigated the issue (e.g., Beltratti \& Stulz, 2012; Erkens et al., 2010; Fahlenbrach \& Stulz, 2011; Minton et al., 2010), however the literature on corporate governance and specifically on the effects of corporate governance in financial institutions is still quite limited (among others, Pathan \& Faff, 2013; Aebi et al., 2012; Liang et al., 2013; Aldalayeen, 2014; Jorfi et al., 2015; Qin \& Dickson, 2017) and the existent results are ambiguous. Furthermore, several challenges remain for future research, also focusing on specific contexts in the light of the distinctive regulation and government intervention experienced by financial institutions (Levine, 2004). Among other challenges, recent studies on bank governance are addressing their attention on risk governance, i.e. on risk management-related corporate governance mechanisms (Miller, 1992; Miccolis \& Shaw, 2000; Cumming \& Mirtle, 2001; Nocco \& Stulz, 2006; Sabato, 2010), because a conscious and appropriate risk management is needful to adequately manage risk in banks (Acharya et al., 2009). Despite both researchers and politicians are recognizing the importance of risk management, the actual role of risk management in a corporate governance context still lacks a common interpretation (Aebi et al., 2012). The studies mainly focus on the direct relationship between corporate governance and risk governance (e.g., Van Greuning \& Brajovic-Bratanovic, 2009) or between risk governance and bank performance (e.g., Aebi et al., 2012; Liu \& Chen, 2012). In order to reach a more complete understanding of the issue, we believe that it is important to consider both the relationships as subsequent steps. In doing so, risk governance would become a mediating variable capable of explaining the effect of corporate governance on bank performance. Put it differently, corporate governance, such as board size, board composition and ownership structure, affects the adoption of risk management-related corporate governance mechanisms and, in turn, bank performance.

With the aim to test the exsistence and the direction of the above-mentioned relationships, we collect data about corporate governance, risk governance and performance for a sample of 31 Italian listed banks over a ten-year period (2008-2017). Italy represents an interesting context of analysis because of the recent regulations which also by receiping the European recommendations have introduced some news on bank governance. Specifically, as the last regulatory intervention is in 2016, after financial crisis, it is worthy to study the effect on the subsequent year. Therefore, although we collect data since 2008 to 2017, we illustrate through descriptive statistics the changes intervened on bank's boards of directors along the years, but we apply the mediation analysis according to the causal steps procedure (Baron \& Kenny 1986; MacKinnon, Fairchild \& Fritz, 2007; Stuetzer et al., 2014) just on the relative variation recorded by performance from 2016 to 2017. We collected governance and performance data for each bank on Bureau Van Dijk Orbis Bank database and by hand on corporate governance annual reports and corporate websites. More in details, we consider as corporate governance measures the board size, the board composition, in terms of gender diversity and board independence, the ownership structure (director ownership, institutional ownership, block ownership). As risk management-related corporate governance mechanisms, we consider the presence of a risk committee, the number of meetings of the risk committee in one year, the number of directors in the risk committee, the percentage of independent directors in the risk committee, and the presence of a chief risk officer (CRO) in the executive board. Finally, we measure bank performance as bank profitability by relative change of the return on total assets (ROA). The main findings suggest that risk governance fully mediates the corporate governance-bank performance relationship. Specifically, we find that the board size is positively related to the presence of a risk committee and to the number of meetings. The percentage of independent directors on board is positively related to the percentage of independent directors in the risky committee and, in turn, has a positive effect on performance. Finally, the presence of institutional owners is positively related to the presence of a CRO and, thus, to bank performance. Summing up, banks with wider and more heterogeneous boards of directors have better risk management-related corporate governance mechanisms and reach higher performance levels.

This study contributes to the existing literature on bank governance by focusing on a specific context, Italy, and thus investigating the effects of the national and European regulations on bank performance after financial crisis. Morover, while previous studies (Aebi et al., 2012) deepen the influence of standard corporate governace on firm performance, we also analyze the mediating role of risk governance. Risk management actually has often a support/control function. However, this role is not sufficient because banks are clearly risky, as also the last financial crisis has demonstrated. Risk management is becoming a driver of profitability as well as an asset for growth and a tool for reductoperational costs, thus legitimating the investigation on antecedents and consequences of risk management-related corporate governance mechanisms.

The remain of the manuscript is structured as follow: in the next paragraph, we present an overview of the regulation about banks' governance and risk in Italy. In the section three, we provide a review of the literature and reach to formulate the research hytpotheses; section four describes the sampling and data collection procedures, defines the variables and illustrates the models applied for the empirical analysis; section five 
discusses the results; finally, section six sums up the concluding remarks.

\section{Literature Review and Hypotheses' Development}

\subsection{Italian Regulation of Banks'Boards and Ownership Structure: An Overview}

Banks' board of directors in Italy are disciplinated by different regulations. First, it receives the European Capital Requirements Directive (CRD IV). It regulates the actions of management bodies and supervisory bodies in order to cope with the harmful effect that bad designed corporate governance structures can have on healthy risk management. In this sense, it drives the Member States to introduce principles and rules to ensure effective control by the governance body, to promote a sound risk culture at all levels of financial firms and to enable competent authorities to monitor the adequacy of internal governance arrangements. It also requires that Member States, in turn, be able to enact additional corporate governance regulations beyond those required by this Directive. Italy, in particular, implemented the CRD IV through the Bank of Italy Circular 285/2013 and subsequently introduced Decree Law 18/2016 to regulate the appointment of members of the administrative and control bodies. Also the article 26 of the TUB regulates on the topic, according to which persons who perform administrative, management and control functions at banks must be suitable for carrying out their duties.They must possess the requisites of professionalism, integrity and independence, satisfy the criteria of competence and fairness, devote the time necessary for the effective performance of the assignment, so as to guarantee the healty and prudent management of the bank.The Minister of Economy and Finance identifies the limits on the accumulation of positions for bank representatives, graduated according to proportionality principles and taking into account the size of the intermediary; as well as the causes that involve the temporary suspension from the office and its duration.

Another important Italian law, to which reference is made when it comes to governance of banks, is the Law 120/2011 which regulates the balance between genders in the bodies of listed companies and therefore, also of listed banks, which are the object of our study. It provides that the division of directors to be elected is carried out on the basis of a criterion that ensures gender balance. The less represented gender must obtain at least one third of the elected directors. If the composition of the board resulting from the election does not comply with this division criterion, the Consob shall inform the company concerned in order to comply with this criterion within a maximum period of four months from the warning. In the event of non-compliance with the warning, the Consob applies a pecuniary administrative sanction from 100,000 euros to 1,000,000 euros, according to criteria and procedures established by its own regulations and sets a new three-month deadline for compliance.

Returning to the CRD IV, in addition to the composition of governance, it also regulates the treatment of risks. In particular, it establishes the work of the management body and regulates the establishment of the risk committee. The management body approves and periodically reviews strategies and policies concerning the assumption, management, monitoring and mitigation of risks to which the institution is or may be exposed, including those deriving from the macroeconomic context in which it operates, in relation to the phase of the economic cycle. The management body must devote sufficient time to the analysis of risk-related matters and actively participate in the management of all substantial risks, as well as the evaluation of the activities. As for the risk committee, it must be established in all those institutions which are significant for their size, internal organization and the nature, breadth and complexity of their activities. The risk committee is composed of members of the management body who do not exercise executive functions within the concerned istitution. Members of the risk committee have adequate knowledge, skills and experience to fully understand and monitor the institution's risk strategy and risk appetite. The committee advises the management body on the overall risk appetite and risk strategy of the institution, both present and future, and assists the management body in monitoring the implementation of this strategy by the high management. The management body retains overall responsibility for risks.

\subsection{The Effects of Corporate Governance on Bank Performance}

Several studies have investigated the effects of corporate governance on bank performance. The most recent ones (e.g., Beltratti \& Stulz, 2012; Fahlenbrach \& Stulz; 2011; Erkens et al., 2010; Cornett et al., 2010) have analyzed the relationship during the credit crisis. For example, Fahlenbrach and Stulz (2011) focus on the effects that CEO incentives have on performance and can not find results that indicate better performance for banks that offer higher salary incentives to CEOs. Beltratti and Stulz (2012), always by investigating the influence of corporate governance on bank performance, during the financial crisis on a sample of 98 banks across the world, find that banks with more shareholder-friendly boards perform worse. This evidence indicates that the widely shared idea that a "good governance" is that in the best interest of shareholders is not always true. Again, Erkens and collegues (2010), on a sample of 296 banks from 30 countries, study the relationship between corporate 
governance and performance of credit institutions during the recent financial crisis. In line with Beltratti and Stulz (2012), they find that the banks recording worse stock returns are those with more independent boards and higher institutional ownership. Finally, Cornett et al. (2010) deepen the effects od different corporate governance mechanisms on bank performance working on a sample of approximately 300 listed US banks. On the contrary to the previous ones (Erkens et al.,2010; Beltratti and Stulz, 2012; Fahlenbrach and Stulz, 2011), their results suggest that better corporate governance (e.g., a more independent board, a higher pay-for-performance sensitivity, and an increase in insider ownership) were positively related to the banks' performance during the recent financial crisis. Good governance mechanisms are actually able to exercise a control on the management and limit opportunistic behaviors. Indeed, they stimulate effective managerial processes that, in turn, improve bank value and generate benefits to all the stakeholders.

In the present work, we look at the years after the crisis and investigate banks' corporate governance (bank governance) in terms of board characteristics and ownership structure.

First, looking at board of directors, already investigated in a limited number of studies (e.g., Adams \& Mehran, 2009; Caprio et al. 2007; Levine 2004; Macey \& O’Hara 2003), we deepen the effects of board size and board composition, that are the core issue of bank corporate governance, on bank performance.

With respect to the board size, different previous studies (Yermack, 1996; Fama \& Jensen, 1983; Jensen, 1983; Florackis \& Ozkan, 2004) suggest that a small number of board directors are important for an effective board. Put it differently, they sustain that large boards of directors expeience less effective coordination, communication, and decision making, and for this reason are often controlled by the CEO. In this direction, Yoshikawa and Phan (2003) suggest that larger boards of directors are less cohesive and a source of potential conflicts among the group members (Forbes \& Milliken, 1999; Lipton \& Lorsch, 1992) and thus tend to be more difficult to coordinate. Besides, Yoshikawa and Han (2003) adfirm that very often are the CEOs interested in creatin large boards of directos in order to disperse the power in the boardroom and mantain a predominant role (Leighton \& Thain, 1997). Differently, smaller boards of directors are more prone to board member participation and this translates in a positive impact on the strategic decision-making capability, on the management autonomy and on the monitoring function (Huther, 1997).

Board composition is another relevant variable to guarantee an effective functioning to the board of directors and to reach better performance (Choe \& Lee, 2003). Board composition can be studied in terms of diversity (heterogeneity), by looking in particular at the participation of women (gender diversity) and independent directors. Up to date, the diversity effects on performance in the financial sector have been studied focusing on racial diversity (Richard, 2000) suggesting that when racial diversity is associated with a growth strategy, productivity improves and the value creation is favored. This can be motivated by the fact that diversity exerts a positive effect on innovative and creative decision making (Bantel and Jackson, 1989). In fact, generally, the most innovative banks are led by directors with high education levels and different functional backgrounds. For example, Hagendorff and Keasey (2012) on a sample of American banks examine the effect of board diversity on the announcement returns for mergers and find a positive one. Moreover, among Academics is borning an increasing interest on gender diversity on boards of directors as a way for enhancing corporate governance. Indeed, a relevant number of studies (e.g., Watson et al., 1993; Fondas \& Sassalos, 2000) suggest that gender diversity on board generates better corporate governance. For instance, Watson and collegues (1993) and Fondas and Sassalos (2000) suggest that diversity on boards in terms of women representation would improve the board's monitoring function in protecting shareholder interests. Therefore, the presence of women on boards makes the monitoring role more effective (Fondas \& Sassalos 2000) and improves boards' ability in solving problems (Watson et al. 1993), thank to women's higher expectations regarding their responsibilities as directors. Therefore, heterogeneity on board generates better decisions and help in finding altervanative solution for emerging problems because of a wider range of perspectives, a more critical approach in analysisng the issues and a more fluid communication (Jackson 1992; Milliken \& Martins 1996). However, despite the importance of female on corporate boards has been long acknowledged (Terjesen and Singh, 2008), up to date women directors in financial istitutions are very few (Arken et al. 2004; Daily et al. 1999). Actually, although the regulations in many European countries have established minimum quotas for women representation on boards, as we have stated in the paragraph 2, the presence of female on boards is still scarce.

Another source of diversity on board is the presence of independent directors. If, on the one hand, manager directors have expertise, dedicated skills, and esteemed knowledge regarding banks' operating policies and day-to-day activities; on the other hand, the presence of independent directors could contribute to the good working of the board by bringing new ideas, objectivity and ability experienced in other field (Weir, 1997; Firth et al., 2002; Cho, 2003). Hence, a greater presence of independent directors may become an important element 
for an effective board (e.g., Yermack, 1996; Fama \& Jensen, 1983), also because it improves the monitoring finction and reduces self-interested actions by managers, by minimizing agency costs (Kiel \& Nicholson, 2003; Le et al. 2006; Florackis \& Ozkan, 2004; Williams et al. 2006). This, in turn, improves bank performance.

Looking at corporate governance in terms of ownership structure, we consider three different perspectives; (a) director ownership, (b) institutional ownership, and block ownership (c). With regard to the director ownership, when directors own shares they are more interested and directly involved in monitoring management operations (Jensen \& Meckling, 1976) and consequently there are less agency problems as compared to the situation where the directors, who are not the shareholders, supervise the management (Seifert et al., 2005). Regarding institutional investors, different authors (e.g., Hussain and Mallin, 2002); Kim and Nofsinger, 2004; Leng, 2004; Soloman and Solomon, 2004; Seifert et al., 2005; Le et al., 2006; Langnan, Steven and Weibin , 2007; Ramzi, 2008) agree on the essential role of institutional shareholders in monitoring because they generally own a relevant number of shares, benefit from their activism and this explains their direct interest in and their effort, may have objective difficulties in liquidating their shares without affecting the share price, have a remarkable influence on the management, and have a professional experience that allows them to adequately monitor executives. Lastly, looking at block ownership, previous studies have suggested that when someone has a relevant amount of interest in a specific economic initiative (usually measured at 5\%), he or she will have a greater incentive in supervisoring management (Kang \& Sorensen, 1999; Maher \& Andersson, 1999; Kim \& Lee, 2003).

\subsection{The Mediating Role of Risk Governance}

With the present work, we do not limit our analysis to the direct effect of corporate governance on bank performance, but aim to explain how this influence happens, thus considering the mediating role of risk related governance mechanisms (risk governance), such as the presence of a risk committee or a chief risk officer in executive board. Over the years, risk management has generally covered the support/control function. However, because the last financial crisis has highlighted that banks are risky businesses and may extend the effects of their failure on the entire market, it is clear that risk governance should hold a more important and powerful role within banks. This circumstance makes the investigation of the issue worthy of attention.

Aebi and collegues (2012), in accordance with Beltratti and Stulz (2012) and Fahlenbrach and Stulz (2011), for example, find that the relation between "standard" corporate governance measures and performance was unsignificant during the crisis, instead the effects of some governance mechanisms, such as board size or board independence, on performance were negative. Besides, they suggest, by providing robust evidence, that the banks, in which the CRO reports directly to the board of directors record better performance than banks in which the CRO reports to the CEO. This evidence suggests that the classical corporate governance structure, where all members of the board directly report to the CEO, is not the most suitable for financial institutions.

This evidence leads us to deepen the role of risk related governance mechanisms. Specifically, we focus on the presence of a risk committee and on its activities and composition and on the presence of a CRO on executive board. First, by looking at the presence of a risk committee, according to previous studies, we link it to better corporate governance. However, just focusing on the presence of a risk committee is not enough, because its characteristics, such as its structure, the degree of independence of the directors in the committee, may have a significant effect. Hence, we consider some additional information over the presence of a risk committee, such as the number of times the risk committee of the respective banks met in 2017 (Nr. of meetings of risk committee), the number of directors in the risk committee (Nr. of directors in risk committee), and the percentage of independent directors in the risk committee (\% of indep. directors in risk committee). Second, we also evaluate if the CRO is or not a member of the executive board (CRO in executive board). We also consider this aspect because is known that when the CRO is a member of the management board, he has larger influence and power whit respect to CRO who works on the third management level. However, greater CRO's influence and power not always are positive for bank value. Geneally, in the short-term the appointment of a CRO is seen as positive, instead in the long-term he could enter in conflict with shareholders. The role of a CRO, indeed, is to reduce the risk exposure, but it is note that high risky activities generate higher profits and returns and, in turn, increase bank value. Hence, when a CRO operates for containing risks, could conflict with shareholders' interesting due to the decreasing of stock prices.

\subsection{Hypotheses}

Eigth hypotheses are developed in this study. They are as follows. First, looking at board characteristics and specifically at board size, on the basis of the above-cited arguments, we expect theoretically that smaller board size should reduce the risk due to its monitoring role in the risk diversifying process of the management. 
Therefore, as smaller boards allow to reduce the agency costs, thank to the independence from the management and to the effective control over the management (Jensen \& Ruback, 1983), we hypothesize that the board size is negatively related to bank performance.

Regarding board composition, and in particular gender diversity, we theorize that banks are prone in making the boards more heterogeneous through the appointment of women directors, because the female presence ensures the possibility of having different perspectives in the decision-making process, resulting in turn in board's better decisions and results (Bear et al. 2010). Also the results found by Francoeur and collegues (2008), finding a positive and significant effect on returns when there is a high proportion of women board members, support our theorization. Similarly, Hambrick and D'Aveni (1992) suggest that board heterogeneity may generate more diverse networking opportunities. This evidence leads us to hypothesize that a higher percentage of women on banks' board of directors is related to better performance.

Regarding the percentage of independent directors, previous research has argued that having a higher proportion of independent directors reduces the agency costs. The idea behind the involvement of a larger number of independent directors on the board is that independent directors could make the board independent from the management and consequently able to monitor the executives effectively (Choe \& Lee, 2003). The research findings of Bhojraj and Sengupta (2003) highligth that boards with stronger representation of outside directors enjoy lower bond yields and higher bond ratings thank to monitoring role of outside directors. Also Brick and Chidambaran (2008) find that a higher percentage of independent directors on board is positively related to bank performance. In the light of these arguments, we posit the following hypotheses:

\section{H1: Board characteristics affect bank performance}

Specifically:

H1.a: Board size is negatively related to bank performance

H1.b: A high percentage of women on board is positively related to bank performance

H1.c: A high percentage of independent directors on board is positively related to bank performance

Over the board characteristics, we measure corporate governance also looking at ownership structure. Regarding to the directors in ownership, their presence would allow to align managers' interests to shareholders' interest, as managers are themselves shareholders. Hence, director ownership could reduce the risk faced by the banks since the directors have the ownership interest to monitor the risk management process of the management (Beatty et al., 1994; Pitts et al., 2003). Looking at the proportion of institutional ownership or block ownership, we hypothesize that if it is higher it could determine a lower risk for the banks because according to Sanders (1999) stock aptions are the best incentive mechanism to limit a company risk.

Therefore, we formulate the following hypotheses:

H2: The ownership structure affects bank performance

Specifically:

H2.a: The presence of director owners is positively related to bank performance

H2.b: The presence of institutional owners is positively related to bank performance

H2.c: The presence of block owners is positively related to bank performance

Finally, we do not limit our study to the direct relationship between corporate governance and bank performance, but aim to investigate the mediating role of risk governance, hypothesizing that a different board size, diverse board composition and ownership structure may affect the adoption of risk-related governance mechanisms and, in turn, bank performance, thus formulating:

H3.a: Risk governance positively mediates the direct relationship between board characteristics and bank performance.

H3.b: Risk governance positively mediates the direct relationship between ownership structure and bank performance

\section{Method}

This section describes the sampling and data collection procedures, defines the variables and the related measures and presents the models for the empirical analysis. 


\subsection{Sample and Data Collection}

Sample includes the 31 Italian listed banks. The data collection process started with the scanning of Bureau van Dijk Orbis Bank, a database containing comprehensive information on banks from all over the world, with the following search criteria: for a bank to be eligible for our study it had to be based in Italy and it had to be listed on the stock market. This process yielded a sample of 31 banks. For each of them, performance and some corporate governance data were collected on the Bureau van Dijk Orbis Bank database. Because of the limited availability of corporate governance and risk governance data on banks in commercial governance databases, we collected banks' annual report and handly set the information about governance variables. In addition, we also made control on banks' websites. This data collection procedure explains, at least in part, why we have a restricted sample. Indeed, this collection process is clearly time-consuming. Moreover, we decided to focus just on listed banks because more information is available for large and more structured banks (Aebi et al., 2012).

The data collection period covered the years since 2008 until 2017, for a total of 5473 observations.

\subsection{Variables and Measures}

Table 1 provides a list of the variables, and related measures, considered in the models of analysis.

Table 1. Variables and measures

\begin{tabular}{|c|c|}
\hline Variables & Measures \\
\hline \multicolumn{2}{|l|}{ Dependent Variables } \\
\hline$R O E$ & $\begin{array}{l}\text { difference between ROE (net income/total equity, ) recorded in } 2017 \text { and ROE recorded in 2016, divided } \\
\text { by the ROE recorded in } 2016\end{array}$ \\
\hline$R O A$ & $\begin{array}{l}\text { difference between ROA (operative income/total assets) recorded in } 2017 \text { and ROA recorded in } 2016 \text {, } \\
\text { divided by the ROA recorded in } 2016\end{array}$ \\
\hline \multicolumn{2}{|l|}{ Control Variables } \\
\hline Total asset & $\log$ of total assets \\
\hline Tier1 capital ratio & tier 1 capital/total risk-weighted assets \\
\hline Deposits/assets & Deposits/total assets \\
\hline Loans/assets & Loans/total assets \\
\hline Board size & natural logarithm of the number of directors on bank's board \\
\hline Gender diversity & proportion of women on board of directors \\
\hline Board independence & percentage of independent directors on board of directors \\
\hline Director ownership & dummy variable with value 1 if at least an owner is also director \\
\hline Institutional ownership & dummy variable with value 1 if at least an institutional owner is also director \\
\hline Block ownership & dummy variable with value 1 if at least a block owner is also director \\
\hline \multicolumn{2}{|l|}{ Mediating Variables } \\
\hline Risk committee & $\begin{array}{l}\text { dummy variable with value } 1 \text { if the bank has a committee enterely dedicated to monitor and manage the } \\
\text { risk }\end{array}$ \\
\hline $\begin{array}{l}\text { Nr. of meetings of risk } \\
\text { committee }\end{array}$ & number of times the risk committee met \\
\hline $\begin{array}{l}\text { Nr. of directors in risk } \\
\text { committee }\end{array}$ & number of directors in the risk committee \\
\hline $\begin{array}{l}\% \text { of indep. directors in risk } \\
\text { committee }\end{array}$ & percentage of independent directors in the risk committee \\
\hline CRO in executive board & dummy variable with value 1 if the CRO is a member of the executive board \\
\hline
\end{tabular}

\subsubsection{Dependent Variables}

We measure bank performance as bank profitability after financial crisis. The first profitability measure we use is the relative change of return on assets $(R O A)$, that is operative income divided by total assets, calculated as the difference between ROA recorded in 2017 and ROA recorded in 2016, divided by the ROA recorded in 2016. We also use (robustness check) the relative change of return on equity $(R O E)$, that is the ratio between net income and total equity, defined as the difference between ROE recorded in 2017 and ROE recorded in 2016, divided by the ROE recorded in 2016. As the results obtained considering both ROA and ROE are very similar, we just report results on ROA. 


\subsubsection{Independent Variables}

Our main independent variables are corporate governance measures. Specifically, we consider the board size, as the natural logarithm of the number of directors on a bank's board (Ln(Board size)) (Yermack, 1996; Adams \& Mehran, 2003).

Second, we look at the the board composition, in terms of gender diversity and board independence. More in detail, in order to catch the gender diversity, we consider the proportion of women on board of directors (Gender diversity) (De Cabo et al., 2012). Instead, we measure board independence by the percentage of independent directors on the board of directors (Board independence). As independent directors we consider the directors without any other relation with the bank over their presence on board. While for non financial institutions, some researchers (e.g., Hermalin \& Weisbach, 1991; Bhagat \& Black, 2002; Hermalin \& Weisbach, 2003) find no significant relation between the percentage of outside directors and firm value, other scholars (Adams, 2009; Beltratti and Stulz, 2012) focusing on financial institutions find that banks with a higher share of independent board members perform worse.

Third, we measure corporate governance looking at the ownership structure. Specifically, we consider a dummy variable with value 1 if at least an owner is also director and with value 0 otherwise (director ownership). To measure the institutional ownership, we build another dummy variable with value 1 if there is at least an institutional owner, 0 otherwise. Finally, we specularly build also a dummy variable for block ownership.

\subsubsection{Mediating Variables}

As risk management-related corporate governance mechanisms, we consider the presence of a risk committee, the number of meetings of the risk committee in one year, the number of directors in the risk committee, the percentage of independent directors in the risk committee, and the presence of a chief risk officer sitting in the executive board.

The presence of a risk committee (Risk committee) is a dummy variable, which is equal to one when the bank has a committee enterely dedicated to monitor and manage the risk. In this case, we expect a better risk governance. As anticipated in the literature part, we also consider some other features characterizing the committee, obviuously for the banks with a risk committee. Specifically, we additionally collect data on the number of times the risk committee of the respective banks met in 2017 (Nr. of meetings of risk committee), the number of directors in the risk committee ( $\mathrm{Nr}$. of directors in risk committee), and the percentage of independent directors in the risk committee (\% of indep. directors in risk committee).

The last variable we collect data on, in order to measure the risk governance mechanisms, looks at the CRO (CRO in executive board). It is a dummy variable with value 1 if the CRO is a member of the executive board, 0 otherwise.

\subsubsection{Control Variables}

As control variables, we consider the bank size (Ln(assets)), measured as the log of total assets recorded in 2015 (Delery \& Doty 1996; Hopkins \& Hopkins 1997); the ratio of tier 1 capital to total risk-weighted assets recorded in 2015 (Tier1 capital ratio) which is an important measure to catch a bank's financial strength; the ratio of deposits to total assets recorded in 2015 (Deposits/assets), which is not subject to runs with deposit insurance (e.g., Gorton, 2010); the ratio of loans to total assets recorded in 2015 (Loans/assets) to catch the asset side of a bank.

\subsection{Analysis}

Hypotheses are tested using a mediation analysis according to the causal steps procedure (Baron \& Kenny 1986; MacKinnon, Fairchild \& Fritz, 2007; Stuetzer et al., 2014). Several steps are followed. In Model 1, we just insert the control variables. Then, we test the direct effect of corporate governance on performance in Models 2 (board characteristics) and in Models 3 (ownership structure). Specifically, Model 2a shows the direct effect of Ln(Board size) on ROA, in Model $2 \mathrm{~b} R O A$ is regressed on gender diversity, in Model 2c the direct effect of board independence on $R O A$ is examined, finally, in Model $2 \mathrm{~d}$ we regress $R O A$ on all board characteristics. Model 3a show the direct effect of director ownership on bank profitability, Model $3 \mathrm{~b}$ presents the direct effect of institutional ownership on ROA, in Model 3c ROA is regressed on block ownership, finally, in Model 3d we regress ROA on all ownership structure measures. We then regress risk governance (Models 4 ) on corporate governance, specifically by considering alternatively as dependent variable Risk Committee in Model 4a, $N r$. of meetings of risk committee in Model $4 \mathrm{~b}, \mathrm{Nr}$. of directors in risk committee in Model $4 \mathrm{c}$, the percentage of independent directors in risk committee in Model 4d, and CRO in executive board as in Model 4e. In Model 5, we estimate the direct effect of risk governance on bank performance. Finally, in Models 6, we test the mediating 
role of risk governance on the corporate governance-ROA relationship. In order to assure the robustness of our results, we also replicate the same analysis considering ROE as main dependent variable.

Before to estimate the models, we ensured the accuracy and consistency of the results. Specifically, we control for heteroskedasticity by applying the Huber White Sandwich estimator and determining the robust standard errors (Rogers, 1993; Wooldridge, 2002). With respect to multicollinearity, we estimate variance inflation factors (VIF test) and the condition index for each regression model. VIF values range from 1 to 2, and the highest value of the condition index equaled 15.63. Hence, we conclude that there is no major problem with multicollinearity (Hair et al., 2010). We winsorize the variables ROE, ROA, Tier 1 capital ratio, Deposits/assets, and Loans/assets at the 1st and 99th percentile. We also carried out a robustness check without winsorizing and we find the same effects. Finally, as another concern in corporate governance studies is endogeneity, we tried to mitigate it, in particular that concerned to reverse causality, by introducing in the models lagged bank characteristics. Instead, unfortunately, we cannot control for endogeneity problems linked to possible correlation between our variables and other variables that we cannot account for. All analyses are performed with STATA statistical software version $\mathrm{IC} / 13$.

\section{Results}

Table 2 reports descriptive statistics for our measures of bank performance, corporate and risk governance, and control variables.

Table 2. Descriptive statistics for dependent, independent and mediating variables

\begin{tabular}{|c|c|c|c|c|c|c|c|c|}
\hline & Mean & Minimum & $\begin{array}{l}\text { Lower } \\
\text { quartile }\end{array}$ & Median & $\begin{array}{l}\text { Upper } \\
\text { quartile }\end{array}$ & Maximum & $\begin{array}{l}\text { Standard } \\
\text { deviation }\end{array}$ & $\mathrm{N}$ \\
\hline \multicolumn{9}{|l|}{ Dependent Variables } \\
\hline$R O E$ & 0.0843 & -0.7658 & 0.0225 & 0.133 & 0.2138 & 0.4236 & 0.2041 & 31 \\
\hline$R O A$ & 0.0074 & -0.0771 & 0.0025 & 0.0121 & 0.0192 & 0.0348 & 0.0191 & 31 \\
\hline \multicolumn{9}{|l|}{ Control Variables } \\
\hline Total asset & 17,805 & 168 & 696 & 1272 & 3441 & 1459,737 & 113,412 & 31 \\
\hline Tierl capital ratio & 0.1134 & 0.0624 & 0.0934 & 0.1074 & 0.1258 & 0.2304 & 0.0303 & 31 \\
\hline Deposits/assets & 0.7391 & 0.4048 & 0.6879 & 0.7517 & 0.8068 & 0.8937 & 0.0939 & 31 \\
\hline Loans/assets & 0.6969 & 0.2477 & 0.6399 & 0.7129 & 0.7788 & 0.9192 & 0.1239 & 31 \\
\hline \multicolumn{9}{|l|}{ Independent variables } \\
\hline Board size & 12.8909 & 7.0000 & 10.0000 & 13.000 & 15.0000 & 20.0000 & 3.0903 & 31 \\
\hline Gender diversity & & & & & & & & 31 \\
\hline Board independence & 0.7785 & 0.3750 & 0.7059 & 0.7857 & 0.8571 & 0.9333 & 0.1027 & 31 \\
\hline Director ownership & 0.4732 & 0.0512 & 0.3991 & 0.4823 & 0.6710 & 0.9117 & 0.2103 & 31 \\
\hline Institutional ownership & 0.5287 & 0.0416 & 0.4009 & 0.5483 & 0.6592 & 0.9397 & 0.2012 & 31 \\
\hline Block ownership & 0.5982 & 0.0523 & 0.4872 & 0.6008 & 0.6973 & 0.9892 & 0.1546 & 31 \\
\hline \multicolumn{9}{|l|}{ Mediating Variables } \\
\hline Risk committee & 0.1980 & 0.0010 & 0.0009 & 0.0000 & 0.0001 & 1.0053 & 0.4127 & 31 \\
\hline Nr. of meetings of risk committee & 3.1123 & 0.0001 & 0.0048 & 3.4271 & 6.584 & 8.472 & 2.6791 & 31 \\
\hline Nr. of directors in risk committee & 3.8182 & 2.897 & 2.6751 & 2.4871 & 4.7862 & 5.9874 & 2.6748 & 31 \\
\hline $\begin{array}{l}\% \text { of indep. directors in risk } \\
\text { committee }\end{array}$ & 0.5321 & 0.0022 & 0.0012 & 0.7917 & 1.0043 & 1.0267 & 0.4542 & 31 \\
\hline CRO in executive board & 0.2678 & 0.00010 & 0.0003 & 0.0007 & 1.5632 & 106072 & 0.4842 & 31 \\
\hline
\end{tabular}

In Table 3, we report the mean value recorded by the same variables since 2008 to 2017. In the last column, we report the results of the t-statistic test, analyzing the mean differences between the value recorded by each variable before the 2016 and after the same year, in order to catch the effect of the regulation introduced in 2016. 
Table 3. Mean value since 2008 to 2017 - mean differences between the value recorded before and after 2016

\begin{tabular}{|c|c|c|c|c|c|c|c|c|c|c|c|}
\hline & 2008 & 2009 & 2010 & 2011 & 2012 & 2013 & 2014 & 2015 & 2016 & 2017 & t-Statistic \\
\hline $\begin{array}{l}\text { Dependent } \\
\text { Variables }\end{array}$ & & & & & & & & & & & \\
\hline$R O E$ & 0.0782 & 0.0543 & 0.0504 & 0.0422 & 0.0489 & 0.0577 & 0.0478 & 0.0657 & 0.0682 & 0.0843 & $0.0164 * *$ \\
\hline $\begin{array}{l}\text { ROA } \\
\text { Control } \\
\text { Variables }\end{array}$ & 0.0126 & 0.0098 & 0.0073 & 0.0065 & 0.0068 & 0.0071 & 0.0085 & 0.0084 & 0.0069 & 0.0074 & $0.0012 *$ \\
\hline Total asset & 15,652 & 14,438 & 14,488 & 15,932 & 15,487 & 14,367 & 14,987 & 15,662 & 16,854 & 17,805 & $78396.12 * * *$ \\
\hline $\begin{array}{l}\text { Tier1 capital } \\
\text { ratio }\end{array}$ & 0.1256 & 0.1096 & 0.0984 & 0.0987 & 0.1014 & 0.1256 & 0.1243 & 0.1299 & 0.1098 & 0.1134 & $-0.0095 * *$ \\
\hline Deposits/assets & 0.7245 & 0.6691 & 0.6879 & 0.6354 & 0.6921 & 0.7265 & 0.6984 & 0.7153 & 0.7401 & 0.7391 & $-0.0399 * * *$ \\
\hline $\begin{array}{l}\text { Loans/assets } \\
\text { Independent } \\
\text { variables }\end{array}$ & 0.6871 & 0.6865 & 0.6743 & 0.6721 & 0.6156 & 0.6723 & 0.6871 & 0.6756 & 0.6945 & $\begin{array}{l}0.6969 \\
\text { Independent } \\
\text { variables }\end{array}$ & $-0.0332 *$ \\
\hline Board size & 11,8986 & 13,6483 & 12.9253 & 12.8904 & 12.8876 & 12.8263 & 13.0089 & 12.9843 & 12.8698 & 12.8909 & $1.6559 * * *$ \\
\hline $\begin{array}{l}\text { Gender } \\
\text { diversity }\end{array}$ & & & & & & & & & & & \\
\hline $\begin{array}{l}\text { Board } \\
\text { independence }\end{array}$ & 0.6285 & 0.6642 & 0.7172 & 0.7522 & 0.7684 & 0.7853 & 0.7922 & 0.7674 & 0.7832 & 0.7785 & 0.0187 \\
\hline $\begin{array}{l}\text { Director } \\
\text { ownership }\end{array}$ & 0,5678 & 0,6824 & 0,6791 & 0,6543 & 0,4569 & 0,6287 & 0,6453 & 0,7453 & 0,4326 & 0.4732 & 0.0187 \\
\hline $\begin{array}{l}\text { Institutional } \\
\text { ownership }\end{array}$ & 0.5672 & 0.5435 & 0.5874 & 0.6453 & 0.5748 & 0.4985 & 0.5893 & 0.5427 & 0.5649 & 0.5287 & $0.1967 * * *$ \\
\hline $\begin{array}{l}\text { Block } \\
\text { ownership } \\
\text { Mediating } \\
\text { Variables }\end{array}$ & 0.5678 & 0.5224 & 0.5453 & 0.5897 & 0.5457 & 0.5378 & 0.5692 & 0.5689 & 0.5486 & 0.5982 & 0.0187 \\
\hline Risk committee & 0.0546 & 0.082 & 0.0356 & 0.0278 & 0.0567 & 0.0986 & 0.0367 & 0.1769 & 0.2167 & 0.1980 & $0.3461 * * *$ \\
\hline $\begin{array}{l}\text { Nr. of meetings } \\
\text { of risk } \\
\text { committee }\end{array}$ & 2,6478 & 2,987 & 3,8672 & 3,876 & 3,625 & 3,756 & 4.1256 & 4.1211 & 4.1532 & 3.1123 & $1.5914 * * *$ \\
\hline $\begin{array}{l}\text { Nr. of directors } \\
\text { in risk } \\
\text { committee }\end{array}$ & 3.5637 & 3.7463 & 3.6271 & 3.2234 & 3.8674 & 3.8142 & 3.8116 & 3.8118 & 3.8689 & 3.8182 & $0.3461 * * *$ \\
\hline $\begin{array}{l}\% \text { of indep. } \\
\text { directors in } \\
\text { risk committee }\end{array}$ & 0.5983 & 0.5522 & 0.5748 & 0.5734 & 0.5678 & 0.59362 & 0.5663 & 0.5627 & 0.5659 & 0.5321 & $0.3461 * * *$ \\
\hline $\begin{array}{l}\text { CRO in } \\
\text { executive } \\
\text { board }\end{array}$ & 0.3647 & 0.3647 & 0.3647 & 0.3647 & 0.3647 & 0.3647 & 0.3647 & 0.3647 & 0.3647 & 0.2678 & $0.3461 * * *$ \\
\hline
\end{tabular}

Table 4 reports the correlation matrix. 
Table 4. Correlation matrix

\begin{tabular}{|c|c|c|c|c|c|c|c|c|c|c|c|c|c|c|c|c|}
\hline & 1. & 2. & 3. & 4. & 5. & 6. & 7. & 8. & 9. & 10. & 11. & 12. & 13. & 14. & 15. & 16. \\
\hline 1.ROE & 1 & & & & & & & & & & & & & & & \\
\hline 2.ROA & -0.115 & 1 & & & & & & & & & & & & & & \\
\hline 3.Ln(assets) & 0.131 & 0.183 & 1 & & & & & & & & & & & & & \\
\hline $\begin{array}{l}\text { 4.Tier1 capital } \\
\text { ratio }\end{array}$ & 0.016 & 0.133 & 0.328 & 1 & & & & & & & & & & & & \\
\hline 5.Deposits/assets & -0.119 & 0.167 & -0.181 & -0.050 & 1 & & & & & & & & & & & \\
\hline 6.Loans/assets & 0.253 & 0.214 & 0.300 & 0.119 & 0.160 & 1 & & & & & & & & & & \\
\hline 7.Ln(Board size) & -0.280 & -0.115 & 0.121 & 0.049 & 0.143 & 0.507 & 1 & & & & & & & & & \\
\hline $\begin{array}{l}\text { 8.Gender } \\
\text { diversity }\end{array}$ & 0.282 & 0.116 & 0.167 & 0.065 & -0.108 & 0.606 & 0.567 & 1 & & & & & & & & \\
\hline $\begin{array}{l}\text { 9.Board } \\
\text { independence }\end{array}$ & 0.270 & 0.151 & 0.173 & 0.083 & 0.150 & 0.527 & 0.600 & 0.590 & 1 & & & & & & & \\
\hline $\begin{array}{l}\text { 10.Director } \\
\text { ownership }\end{array}$ & 0.312 & 0.079 & 0.158 & 0.059 & 0.067 & 0.326 & 0.373 & 0.369 & 0.443 & 1 & & & & & & \\
\hline $\begin{array}{l}\text { 11.Institutional } \\
\text { ownership }\end{array}$ & 0.286 & 0.047 & 0.105 & 0.016 & 0.046 & 0.221 & 0.271 & 0.266 & -0.233 & 0.544 & 1 & & & & & \\
\hline $\begin{array}{l}\text { 12.Block } \\
\text { ownership }\end{array}$ & 0.225 & 0.088 & 0.032 & 0.063 & 0.017 & 0.367 & -0.345 & 0.378 & 0.478 & 0.567 & 0.352 & 1 & & & & \\
\hline $\begin{array}{l}\text { 13.Nr. of } \\
\text { meetings of risk } \\
\text { committee }\end{array}$ & 0.287 & 0.052 & 0.067 & 0.082 & 0.036 & 0.322 & 0.723 & 0.354 & 0.647 & 0.326 & 0.326 & 0.369 & 1 & & & \\
\hline $\begin{array}{l}\text { 14.Nr. of } \\
\text { directors in risk } \\
\text { committee }\end{array}$ & 0.436 & -0.049 & 0.089 & 0.064 & -0.048 & 0.456 & 0.267 & 0.321 & 0.378 & -0.782 & 0.367 & 0.373 & 0.343 & 1 & & \\
\hline $\begin{array}{l}\text { 15.\% of indep. } \\
\text { directors in risk } \\
\text { committee }\end{array}$ & 0.552 & -0.073 & 0.147 & 0.015 & 0.167 & 0.897 & 0.289 & 0.387 & 0.583 & 0.524 & 0.489 & 0.389 & 0.385 & 0.498 & 1 & \\
\hline $\begin{array}{l}\text { 16.CRO in } \\
\text { executive board }\end{array}$ & 0.692 & -0.065 & 0.167 & 0.089 & 0.178 & 0.452 & 0.452 & 0.672 & 0.241 & 0.478 & 0.256 & 0.342 & 0.371 & 0.367 & 0.256 & 1 \\
\hline
\end{tabular}

The results of the regressions are shown in Tables 5,6,7 and 8 .

Table 5. The effect of board characteristics on bank performance

\begin{tabular}{|c|c|c|c|c|c|}
\hline & $R O A$ & $R O A$ & $R O A$ & $R O A$ & $R O A$ \\
\hline Control Variables & Model 1 & Model $2 a$ & Model $2 b$ & Model 2c & Model 2d \\
\hline Ln(assets) & $0.018 * *$ & $0.103 * *$ & $0.098 *$ & $0.048^{*}$ & $0.267 *$ \\
\hline Tier1 capital ratio & $0.835 * *$ & $1.773 * *$ & $0.027 * *$ & $0.692 * *$ & $0.254 *$ \\
\hline Deposits/assets & 0.118 & 0.678 & 0.494 & 0.055 & 0.067 \\
\hline Loans/assets & 0.909 & 0.730 & 0.858 & 1.383 & 0.895 \\
\hline \multicolumn{6}{|l|}{ Independent variables } \\
\hline Ln(Board size) & & $-0.293 * * *$ & & & $-0.236 * * *$ \\
\hline Gender diversity & & & $0.452 *$ & & $0.193 *$ \\
\hline Board independence & & & & $0.321 *$ & $0.536^{*}$ \\
\hline $\mathrm{N}$ & 124 & 154 & 155 & 153 & 217 \\
\hline $\mathrm{R}^{2}$ & 0.11 & 0.15 & 0.19 & 0.14 & 0.29 \\
\hline $\mathrm{R}^{2}$ - Adjusted & 0.06 & 0.08 & 0.11 & 0.09 & 0.15 \\
\hline
\end{tabular}

* Significance at the $10 \%$ level; ** Significance at the $5 \%$ level; *** Significance at the $1 \%$ level.

Table 5 reports the effects of board characteristics on ROA. Model 1 just shows the effect of control variables, highlighting that the bank size (Ln(assets)) and the Tier 1 capital ratio are significantly and positively related to the return on assets. Model 2a shows the negative effect of board size on performance, thus not supporting hypothesis 1a. The effect of the percentage of women on board is shown in Model $2 \mathrm{~b}$ and proves to be positive 
but scarcely significant as the effect of the percentage of independent directors shown in Model 2c, supporting hypotheses $2 \mathrm{~b}$ and $2 \mathrm{c}$. Finally, Model $2 \mathrm{~d}$ shows the conjunct effect of the three board characteristics we measure on ROA. Summing up, wider boards with a high percentage of women and independent directors reach better performance.

Table 6. The effect of ownership structure on bank performance

\begin{tabular}{|c|c|c|c|c|}
\hline & $R O A$ & $R O A$ & $R O A$ & $R O A$ \\
\hline Control Variables & Model $3 a$ & Model $3 b$ & Model 3c & Model $3 d$ \\
\hline Ln(assets) & $0.022 * *$ & $0.189 * *$ & $0.822 *$ & $0.053 *$ \\
\hline Tier1 capital ratio & $0.563^{*}$ & $1.253^{*}$ & $0.0267 *$ & $0.782 *$ \\
\hline Deposits/assets & 0.567 & 0.612 & 0.278 & 0.055 \\
\hline Loans/assets & 0.822 & 0.892 & 0.692 & 1.263 \\
\hline \multicolumn{5}{|l|}{ Independent Variables } \\
\hline Director ownership & 0.265 & & & 0.226 \\
\hline Institutional ownership & & $0.176^{* *}$ & & $0.278^{* * *}$ \\
\hline Block ownership & & & -0.286 & -0.427 \\
\hline $\mathrm{N}$ & 149 & 151 & 154 & 210 \\
\hline $\mathrm{R}^{2}$ & 0.17 & 0.18 & 0.15 & 0.17 \\
\hline $\mathrm{R}^{2}$ - Adjusted & 0.09 & 0.10 & 0.08 & 0.10 \\
\hline
\end{tabular}

* Significance at the $10 \%$ level; ** Significance at the $5 \%$ level; *** Significance at the $1 \%$ level.

Table 6 reports the results about the effects of ownership structure on bank performance. In Model $3 b$, it highlights the positive effect of institutional ownership on ROA, while the effects of directors ownership (Model 3a) and block ownership (Model 3c) seem to be not significant. Therefore, just hypothesis $2 b$ is supported. The results remain the same also when considering the conjunct effect of the three ownership structure's variables (Model 3d). Put it differently, just the presence of institutional owners seems to lead to better performance.

Table 7. The effect of board characteristics on risk governance

\begin{tabular}{|c|c|c|c|c|c|}
\hline & $\begin{array}{l}\text { Risk } \\
\text { committee }\end{array}$ & $\begin{array}{l}\text { Nr. of meetings of risk } \\
\text { committee }\end{array}$ & $\begin{array}{l}\text { Nr. of directors in risk } \\
\text { committee }\end{array}$ & $\begin{array}{l}\% \text { of indep. directors in } \\
\text { risk committee }\end{array}$ & $\begin{array}{l}\text { CRO in executive } \\
\text { board }\end{array}$ \\
\hline Control Variables & Model $4 a$ & Model $4 b$ & Model $4 c$ & Model $4 d$ & Model $4 e$ \\
\hline Ln(assets) & 0.024 & $-0.105^{* *}$ & $-0.037 *$ & -0.289 & -0.223 \\
\hline Tier 1 capital ratio & 0.867 & 0.789 & 0.062 & 0.345 & 0.782 \\
\hline Deposits/assets & -0.128 & -0.782 & -0.762 & -0.126 & -0.172 \\
\hline Loans/assets & -0.238 & -0.933 & -0.091 & -0.328 & -0.672 \\
\hline \multicolumn{6}{|l|}{ Independent variables } \\
\hline Ln(Board size) & $0.252 * * *$ & $0.378 * * *$ & 0.367 & 0.367 & 0.786 \\
\hline Gender diversity & -0.256 & 0.312 & 0.372 & 0.382 & 0.546 \\
\hline $\begin{array}{l}\text { Board } \\
\text { independence }\end{array}$ & -0.286 & 0.499 & 0.271 & $0.356^{* *}$ & 0.234 \\
\hline Director ownership & -0.237 & 0.378 & 0.289 & 0.267 & 0,523 \\
\hline $\begin{array}{l}\text { Institutional } \\
\text { ownership }\end{array}$ & -0.269 & 0.367 & 0.251 & 0.229 & $0.273 * * *$ \\
\hline Block ownership & -0.267 & 0.278 & 0.256 & 0.286 & 0.862 \\
\hline $\mathrm{N}$ & 206 & 204 & 202 & 206 & 208 \\
\hline $\mathrm{R}^{2}$ & 0.38 & 0.33 & 0.31 & 0.36 & 0.38 \\
\hline $\mathrm{R}^{2}$ - Adjusted & 0.19 & 0.18 & 0.12 & 0.17 & 0.19 \\
\hline
\end{tabular}

* Significance at the $10 \%$ level; ** Significance at the $5 \%$ level; *** Significance at the $1 \%$ level.

Table 7 reports the results of regression models investigating the effects of corporate governance variables (board characteristics and ownership structure) on risk governance. More in details, Model 4a shows the positive effect of board size on Risk committee. Model $4 \mathrm{~b}$ suggests the significant and positive effect of board size on the number of meetings of risk committee. The percentage of independent directors on board has, instead, a positive 
effect on the percentage of independent directors on risk committee, as show in Model 4d. Finally, the institutional ownership has a positive effect on the presence of a CRO in executive board. Summing up, banks with wider board od directors have a risk committee that moreover organizes a higher number of meetings in one year; if the percentage of independent directors is higher on board of directors, consequently, it is higher also on risk committee; finally, the presence of institutional owners is positively linked to the presence of a CRO in executive board, maybe in order to guarantee a grater control.

Table 8. The mediating role of risk governance

\begin{tabular}{|c|c|c|c|}
\hline & $R O A$ & $R O A$ & $R O A$ \\
\hline Control Variables & Model 5 & Model $6 a$ & Model $6 b$ \\
\hline Ln(assets) & $0.032 * *$ & $0.052 * *$ & $0.055^{* *}$ \\
\hline Tier 1 capital ratio & $0.245^{*}$ & $0.326^{*}$ & $0.278^{*}$ \\
\hline Deposits/assets & 0.167 & 0.278 & 0.128 \\
\hline Loans/assets & 0.324 & 0.432 & 0.289 \\
\hline \multicolumn{4}{|l|}{ Independent Variables } \\
\hline Ln(Board size) & $-0.289 * *$ & & -0.178 \\
\hline Gender diversity & $0.678^{*}$ & & 0.456 \\
\hline Board independence & $0.298^{*}$ & & 0.679 \\
\hline Director ownership & 0.187 & & 0.365 \\
\hline Institutional ownership & $0.278 * *$ & & 0.874 \\
\hline Block ownership & 0.189 & & 0.736 \\
\hline \multicolumn{4}{|l|}{ Mediating Variables } \\
\hline Risk committee & & $0.167 * * *$ & $0.635 * * *$ \\
\hline Nr. of meetings of risk committee & & $0.564 * *$ & $0.367 * *$ \\
\hline Nr. of directors in risk committee & & 0.356 & 0.487 \\
\hline$\%$ of indep. directors in risk committee & & $0.376^{* *}$ & $0.226^{* *}$ \\
\hline CRO in executive board & & $0.453 *$ & $0.217 *$ \\
\hline $\mathrm{N}$ & 278 & 267 & 289 \\
\hline $\mathrm{R}^{2}$ & 0.38 & 0.36 & 0.42 \\
\hline $\mathrm{R}^{2}$ - Adjusted & 0.21 & 0.22 & 0.29 \\
\hline
\end{tabular}

* Significance at the $10 \%$ level; ** Significance at the $5 \%$ level; *** Significance at the $1 \%$ level.

Table 8 illustrates the mediating effect of risk governance on the direct relationship corporate governance-bank performance. Model 5 just shows the effects of risk management-related corporate governance mechanisms on ROA suggesting the significant and positive effect of the presence of a risk committee, the number of meetings, the percentage of independent directors on risk committee and the presence of a CRO in the executive board. In Model 6a, ROA is regressed on board characteristics and risk governance. The results suggest the mediation role of risk governance (risk committee, number of meetings of risk committee, percentage of independent directors on risk committee) and support hypotheses 3a. In Model 6b, ROA is regressed on ownership structure and risk governance. The results suggest the mediation role of risk governance (risk committee, number of meetings of risk committee, percentage of independent directors on risk committee) and support hypotheses $3 \mathrm{~b}$. Put it differently, when risk management-related corporate governance mechanisms are added to the main effects, corporate governance variables lose their significance indicating a full mediation of risk governance. In other words, the positive effect of such corporate governance variables is explained by the positive effect that they have on risk governance.

Besides, we conducted some robustness checks (MacKinnon, Lockwood, Hoffman, West, \& Sheets, 2002), by considering as dependent variable ROE. Also in this case, the mediation effect remains.

\section{Conclusion}

In this paper, we analyze how bank governance (board size, board composition, ownership structure) affects performance (ROA), by considering the mediating role of risk governance (presence of a risk committee, the number of meetings of the risk committee in one year, the risk committee size, the percentage of independent directors in the risk committee, and the presence of a chief risk officer). The main findings suggest that risk governance fully mediates the corporate governance-bank performance relationship. Specifically, we find that the board size is positively related to the presence of a risk committee and to the number of meetings. The 
percentage of independent directors in board is positively related to the percentage of independent directors in the risky committee and, in turn, has a positive effect on performance. Finally, the presence of institutional owners is positively related to the presence of a chief risk officer and, thus, to bank performance. Summing up, banks with wider and more heterogeneous boards of directors have better risk management-related corporate governance mechanisms and reach higher performance levels.

Despite the interesting results, the study suffers from some limitations. First, the analysis is just on two years (2016 and 2017), but we have data available to carry out a panel analysis, also with GMM, and try to catch the regulation changes over the years. Moreover, we could consider other control variables, such as the risk and the degree of system competition that are determining factor for bank profitability.

\section{References}

Acharya, V., Philippon, T., Richardson, M., \& Roubini, N. (2009). The financial crisis of 2007-2009: causes and remedies. In Acharya, V., Richardson, M. (Eds.), Restoring Financial Stability. John Wiley \& Sons, New York. Retrieved from https://onlinelibrary.wiley.com/doi/abs/10.1111/j.1468-0416.2009.00147_2.x

Adams, R. B. (2009). Governance and the financial crisis. ECGI Finance Working Paper, 248. Retrieved from https://onlinelibrary.wiley.com/doi/full/10.1111/j.1468-2443.2011.01147.x

Adams, R. B., \& Mehran, H. (2003). Is corporate governance different for bank holding companies? Federal Reserve Bank of New York Economic Policy Review, 9, 123-142. Retrieved from https://www.newyorkfed.org/research/epr/03v09n1/0304adam.html

Aebi, V., Sabato, G., \& Schmid, M. (2012). Risk management, corporate governance, and bank performance in the financial crisis. Journal of Banking \& Finance, 36(12), 3213-3226. Retrieved from https://www.sciencedirect.com/science/article/pii/S0378426611003104

Aldalayeen, B. (2014). Corporate Governance and Bank Performance in Nigeria: Further Evidence from Nigeria. International Journal of Business and Management, 9(8), 133-139. Retrieved from http://www.ccsenet.org/journal/index.php/ijbm/article/view/26714

Alexander, K. (2006). Corporate Governance and Banks: The Role of Regulation in Reducing the Principal-Agent Problem. Journal of Banking Regulation, 2(1/2), 17-40. Retrieved from https://link.springer.com/article/10.1057/palgrave.jbr.2340003

Arken, D. E., Bellar, S. L., \& Helms, M. M. (2004). The ultimate glass ceiling revisited: The presence of women on corporate boards. Journal of Business Ethics, 50, 177-185. Retrieved from https://link.springer.com/article/10.1023/B:BUSI.0000022125.95758.98

Bantel, K. A., \& Jackson, S. E. (1989). Top management and innovations in banking: Does the composition of the top team make a difference? Strategic Management Journal, 10, 107-124. Retrieved from https://onlinelibrary.wiley.com/doi/abs/10.1002/smj.4250100709

Baron, R. M., \& Kenny, D. A. (1986). The moderator-mediator variable distinction in social psychological research: Conceptual, strategic, and statistical considerations. Journal of Personality and Social Psychology, 51(6), 1173-1182. https://doi.org/10.1037/0022-3514.51.6.1173

Basel Committee on Banking Supervision. (2006). International convergence of capital measurement and capital standards.

Bear, S., Rahman, N., \& Post, C. (2010). The impact of board diversity and gender composition on corporate social responsibility and firm reputation. Journal of Business Ethics, 97, 207-221. Retrieved from https://link.springer.com/article/10.1007/s10551-010-0505-2

Beatty, Randolph, P., Zajac, \& Edward, J. (1994). Managerial incentives, monitoring, and risk bearing: A study of executive compensation, ownership, and board structure in initial public offering. Administrative Science Quarterly, 39(2), 313-335. Retrieved from https:/onlinelibrary.wiley.com/doi/abs/10.1111/j.1745-6622.1995.tb00291.x

Beltratti, A., \& Stulz, R. M. (2012). The credit crisis around the globe: Why did some banks perform better during the credit crisis? Journal of Financial Economics, 105(1), 1-17. Retrieved from https://www.sciencedirect.com/science/article/pii/S0304405X11002790

Benkraiem R. (2008). The Influence of Institutional Investors on Opportunistic Earnings Management. International Journal of Accounting, Auditing and Performance Evaluation, 5(1), 89-106.

Bhagat, S., \& Black, B. S. (2002). The non-correlation between board independence and long-term firm 
performance. Journal of Corporation Law, 27, 231-273. Retrieved from https://law.stanford.edu/publications/the-non-correlation-between-board-independence-and-long-term-firmperformance/

Bhojraj S., \& Sengupta, P. (2003). Effect of Corporate Governance on Bond Ratings and Yields: The Role of Institutional Investors and Outside Directors. Journal of Business, 76(3), 455-475.

Brick, I. E., \& Chidambaran, N. K. (2008). Board monitoring, firm risk, and external regulation. Journal of Regulatory Economics, 33(1), 87-116. Retrieved from https://link.springer.com/article/10.1007/s11149-007-9045-9

Caprio, G., Laeven, L., \& Levine, R. (2007). Governance and banks valuations. Journal of Financial Intermediation, 16, 584-617. https://www.sciencedirect.com/science/article/pii/S1042957307000198

Cebenoyan, S. \& Strahan, P. E. (2001). Risk management, capital structure and lending at banks. Retrieved from http://fic.wharton.upenn.edu/ fic/papers/02/0209.pdf

Choe, H., \& Lee, B. S. (2003). Korean Bank Governance Reform after the Asian Financial Crisis. Pacific-Basin Finance Journal, 11, 483-508. $\quad$ Retrieved from https://www.sciencedirect.com/science/article/pii/S0927538X03000519

Cornett, M. M., McNutt, J. J., \& Tehranian, H. (2010). The financial crisis, internal corporate governance, and the performance of publicly-traded US bank holding companies. Working Paper, Boston College.

Cumming, C., \& Mirtle, B. (2001). The challenges of risk management in diversified financial institutions. Federal Reserve Bank of New York Economic Policy Review, 7, 1-17. Retrieved from https://www.newyorkfed.org/research/epr/01v07n1/0103cumm.html

Daily, C., Certo, T., \& Dalton, D. (1999). A decade of corporate women: Some progress in the boardroom, none in the executive suite. Strategic Management Journal, 20, 93-99. Retrieved from https://onlinelibrary.wiley.com/doi/abs/10.1002/\%28SICI\%291097-0266\%28199901\%2920\%3A1\%3C93\% 3A\%3AAID-SMJ18\%3E3.0.CO\%3B2-7

de Cabo, R. M., Gimeno, R., \& Nieto M. J. (2012). Gender Diversity on European Banks' Boards of Directors. Journal of Business Ethics, 109, 145-162. https://ink.springer.com/article/10.1007/s10551-011-1112-6

Delery, J. E., \& Doty, D. H. (1996). Theoretical frameworks in strategic human resource management: Universalistic, contingency, and configurational perspectives. Academy of Management Journal, 39, 802-835. Retrieved from https://journals.aom.org/doi/10.5465/256713

Diamond, D. W., \& Rajan, R. G. (2009). The credit crisis: conjectures about causes and remedies. American Economic Review, 99, 606-610. http://www.nber.org/papers/w14739

Erkens, D., Hung, M., \& Matos, P. (2010). Corporate governance in the 2007-2008 financial crisis: evidence from financial institutions worldwide. Working Paper, University of Southern California.

Fahlenbrach, R., Stulz, \& R. M. (2011). Bank CEO incentives and the credit crisis. Journal of Financial Economics, 99, 11-26. from https://www.sciencedirect.com/science/article/pii/S0304405X10001868

Fama, E. F., \& Jensen, M. C. (1983). Separation of ownership and control. Journal of Law and Economics, 26, $301-325$

Flannery, M. J. (1998). Using market information in prudential bank supervision: a review of the US empirical evidence. Journal of Money, Credit and Banking, 30, 273-305.

Florackis, C., \& Ozkan, A. (2004). Agency Costs and Corporate Governance Mechanisms: Evidence for UK firms. Retrieved from http://www.soc.uoc.gr/asset/accepted papers/paper87.pdf.

Fondas, N., \& Sassalos, S. (2000). A different voice in the boardroom: How the presence of women directors affects board influence over management. Global Focus, 12, 13-22.

Forbes, D. P., \& Milliken, F. J. (1999). Cognition and corporate governance: Understanding boards of directors as strategic decision-making groups. Academy of Management Review, 24(3), 489-505.

Francoeur, C., Labelle, R., \& Sinclair-Desgagne, B. (2008). Gender diversity in corporate governance and top $\begin{array}{lllll}\text { management. Journal of Business } & \text { Ethics, } & 81, & \text { 83-95. }\end{array}$ https://link.springer.com/article/10.1007/s10551-007-9482-5

Garcia-Marco, T., \& Robles-Fernandex, M. D. (2008). Risk-Taking Behavior and Ownership in the Banking 
Industry: The Spanish Evidence. Journal of Economics and Business, 60, 332-354. Retrieved from https://www.sciencedirect.com/science/article/pii/S0148619507000434

Gorton, G. (2010). Slapped by the Invisible Hand. Oxford: Oxford University Press.

Hagendorff, J., \& Keasey, K. (2012). The value of board diversity in banking: Evidence from the market for corporate control. European Journal of Finance, 18(1), 41-58. Retrieved from https://www.tandfonline.com/doi/abs/10.1080/1351847X.2010.481471

Hambrick, D. C., \& D'Aveni, R. A. (1992). Top team deterioration as part of the downward spiral of large corporate bankruptcies. Management Science, 38, 1445-1466.

Hermalin, B. E., \& Weisbach, M. S. (1991). The effects of board composition and direct incentives on firm performance. Financial Management, 20, 101-112.

Hermalin, B. E., Weisbach, M. S. (2003). Boards of directors as an endogenously determined institution: a survey of the economic literature. Federal Reserve Bank of New York Economic Policy Review, 9, 7-26.

Hopkins, W. E., \& Hopkins, S. A. (1997). Strategic planning-financial performance relationships in banks: A causal examination. Strategic Management Journal, 18, 635-652. Retrieved from https://onlinelibrary.wiley.com/doi/abs/10.1002/\%28SICI\%291097-0266\%28199709\%2918\%3A8\%3C635 $\% 3 \mathrm{~A} \% 3 \mathrm{AAID}-\mathrm{SMJ} 904 \% 3 \mathrm{E} 3.0 . \mathrm{CO} \% 3 \mathrm{~B} 2-\% 23$

Hussain, S. H., \& Mallin, C. (2002). Corporate Governance in Bahrain. Corporate Governance: An International Review, 10(3), 197-210. Retrieved from https:/onlinelibrary.wiley.com/doi/pdf/10.1111/1467-8683.00284

Huther, J. (1997). An Empirical Test of the Effect of Board Size on Firm Efficiency. Economics Letter, 54, 259-264. Retrieved from https://www.sciencedirect.com/science/article/pii/S0165176597000359

Jackson, S. (1992). Consequences of group composition for the interpersonal dynamics of strategic issue processing. In Shrivastava, P., Huff, A., \& Dutton J. (Eds.), Advances in strategic management (Vol. 8, pp. 345-382). Greenwich, CT: JAI Press.

Jensen, M. C. (1993). The modern industrial revolution, exit, and the failure of internal control systems. Journal of Finance, $48, \quad 831-880 . \quad$ Retrieved from https://onlinelibrary.wiley.com/doi/abs/10.1111/j.1540-6261.1993.tb04022.x

Jensen, M. C., \& Meckling, W. H. (1976). Theory of the Firm: Managerial Behavior, Agency Costs and Ownership Structure. Journal of Financial Economics, 3(4), 305-360. Retrieved from https://www.sciencedirect.com/science/article/pii/0304405X7690026X

Jorfi, H., Jorfi, S., Yaccob, H. F. B., \& Shah, I. M. (2015). Ownership Concentration and Bank Performance: Evidence from MENA Banks. International Journal of Business and Management, 10(3), 189-202. Retrieved from http://www.ccsenet.org/journal/index.php/ijbm/article/view/43175

Kang, D. L., \& Sorensen, A. B. (1999). Ownership Organization and Firm Performance. Annual Review, 25, 121-44. Retrieved from https://www.annualreviews.org/doi/10.1146/annurev.soc.25.1.121

Kiel, G. C., \& Nicholson, G. J. (2003). Board composition and corporate performance: How the Australian experience informs contrasting theories of corporate governance. Corporate Governance: An International Review, 11, 189-205. Retrieved from https://onlinelibrary.wiley.com/doi/abs/10.1111/1467-8683.00318

Kim, B., \& Lee, I. (2003). Agency Problems and Performance of Korean Companies during the Asian Financial Crisis: Chaebol vs. Nonchaebol Firms. Pacific-Basin Finance Journal, 11, 327-348. Retrieved from https://www.sciencedirect.com/science/article/pii/S0927538X03000271

Kim, K. A., \& Nofsinger, J. R. (2004). Corporate Governance. Pearson Prentice Hall: New Jersey.

Kirkpatrick, G. (2009). The corporate governance lesson from the financial crisis. OECD Financial Market Trends Report.

Langnan, C., Steven, L., \& Weibin, L. (2007). Corporate Governance and Corporate Performance: Some Evidence from Newly Listed Firms on Chinese Stock Markets. International Journal of Accounting, Auditing and Performance Evaluation, 4(2), 183-197.

Le, S. A., Walters, B., \& Kroll, M. (2006). The Moderating Effects of External Monitors on the Relationship between R and D Spending and Firm Performance. Journal of Business Research, 59, 278-287. Retrieved from https://www.sciencedirect.com/science/article/pii/S0148296305000561

Leighton, D. S. R., \& Thain, D. H. (1997). Making boards work: What directors must do to make Canadian 
boards effective. Whitby, Ontario: McGraw-Hill Ryerson.

Leng, A. C. A. (2004). The Impact of Corporate Governance Practices on Firms' Financial Performance: Evidence from Malaysian Companies. ASEAN Economic Bulletin, 21(3), 308-318.

Levine, R. (2004). The corporate governance of banks: a concise discussion of concepts and evidence. World Bank Policy Research Working Paper, 3404.

Lipton, M., \& Lorsch, J. W. (1992). A modest proposal for improved corporate governance. Business Lawyer, 48, 59-77.

Liu, X., \& Chen, Y. (2012). Studying the Role of Financial Risk Management on Return on Equity. International Journal of Business and Management, 7(9), 215-221. Retrieved from http://www.ccsenet.org/journal/index.php/ijbm/article/viewFile/13514/11321Studying

Macey, J. R., \& O'Hara, M. (2003). The corporate governance of banks. Federal Reserve Bank of New York Economic Policy Review, 9, 91-107. Retrieved from https://www.newyorkfed.org/research/epr/03v09n1/0304mace.html

MacKinnon, D. P., Fairchild, A. J., \& Fritz, M. S. (2007). Mediation analysis. Annual Review of Psychology, 58, 593-614. Retrieved from https://www.annualreviews.org/doi/10.1146/annurev.psych.58.110405.085542

Maher, M., \& Andersson, T. (1999). Corporate governance: Effects on firm performance and economic growth. Retrieved from http://www.oecd.org/ dataoecd/10/34/2090569.pdf

Miccolis, J., \& Shaw, S. (2000). Enterprise Risk Management: An Analytic Approach. Tillinghast - Towers Perrin, New York.

Miller, K. D. (1992). A framework for integrated risk management in international business. Journal of International Business Studies, 23, 311-331. Retrieved from https://link.springer.com/article/10.1057/palgrave.jibs. 8490270

Milliken, F. J., \& Martins, L. L. (1996). Searching for common threads: Understanding the multiple effects of diversity in organizational groups. Academy of Management Review, 21(2), 402-433. Retrieved from https://journals.aom.org/doi/10.5465/AMR.1996.9605060217

Minton, B., Taillard, J. P. A., \& Williamson, R. (2010). Do independence and financial expertise of the board matter for risk taking and performance? Working Paper, Ohio State University.

Myers, S. C. (1977). Determinants of corporate borrowing. Journal of Financial Economics, 5, 147-175. Retrieved from https://www.sciencedirect.com/science/article/pii/0304405X77900150

Nocco, B. W., \& Stulz, R. M. (2006). Enterprise risk management: theory and practice. Journal of Applied Corporate Finance, $\quad 18, \quad 8-20 . \quad$ Retrieved from https://onlinelibrary.wiley.com/doi/abs/10.1111/j.1745-6622.2006.00106.x

Pitts, M., Sadler, G. V., \& Conyon, M. J. (2003). Corporate Boards and Incentives: Empirical Evidence from the UK in 1935. Corporate Ownership and Control, 1(1), 129-138. Retrieved from https://www.virtusinterpress.org/CORPORATE-BOARDS-AND-INCENTIVES.html

Richard, O. C. (2000). Racial diversity, business strategy, and firm performance: A resource-based view. Academy of Management Journal, 43(2), 164-177. Retrieved from https://journals.aom.org/doi/10.5465/1556374

Rogers, W. H. (1993). Regression Standard Errors in Clustered Samples. Stata Technical Bulletin, 3(13), 19-23.

Sabato, G. (2010). Financial crisis: where did risk management fail? International Review of Applied Financial Issues and Economics, 2, 12-18.

Sanders, G. (1999). Incentive Structue of CEO Stock Option Pay and Stock Ownership: The Moderating Effects for Firm Risk. Managerial Finance, 25(10), 61-75. Retrieved from https://www.emeraldinsight.com/doi/pdfplus/10.1108/03074359910766235

Seifert, B., Gonenc, H., \& Wright, J. (2005). The International Evidence on Performance and Equity Ownership by Insiders, Blockholders, and Institutions. Journal of Multinational Financial Management, 15, 171-191. https://www.sciencedirect.com/science/article/pii/S1042444X04000465

Solomon, J., \& Solomon, A. (2004). Corporate Governance and Accountability. John Wiley and Sons Ltd, West Sussex, England. 
Srivastav A., Hagendorff, J. (2016). Corporate Governance and Bank Risk-taking. Corporate Governance: An International Review, 24(3), 334-345. https://onlinelibrary.wiley.com/doi/abs/10.1111/corg.12133

Stuetzer, M., Obschonka, M., Brixy, U., Sternberg, R., \& Cantner, U. (2014). Regional characteristics, opportunity perception and entrepreneurial activities. Small Business Economics, 42(2), 221-244. Retrieved from https://link.springer.com/article/10.1007/s11187-013-9488-6

Van Greuning, H., \& Brajovic Bratanovic, S. (2003). Analyzing and Managing Banking Risk: A Framework for Assessing Corporate Governance and Financial Risk. Washington, D.C.: World Bank Publications.

Van Greuning, H., \& Brajovic-Bratanovic, S. (2003). Analyzing and managing banking risk: A framework for assessing corporate governance and financial risk (2nd ed.). No 20043, The World Bank.

Watson, W. E., Kumar, K., \& Michaelsen, L. K. (1993). Cultural diversity's impact on interaction process and performance: Comparing homogeneous and diverse task groups. Academy of Management Journal, 36(3), 590-602. Retrieved from https://journals.aom.org/doi/10.5465/256593

Williams, D. R., Duncan, W. J., Ginter, P. M., \& Shewchuk, R. M. (2006). Do governance, equity characteristics, and venture capital involvement affect long-term wealth creation in US health care and biotechnology IPOs? Journal of Health Care Finance, 33(1), 54-71.

Wooldridge, J. M. (2002). Econometric Analysis of Cross-Section and Panel Data. MIT Press, Boston.

Yermack, D. (1996). Higher market valuation of companies with a small board of directors. Journal of Financial Economics, 40, 185-211. Retrieved from https://www.sciencedirect.com/science/article/pii/0304405X95008445

Yoshikawa, T., \& Phan, P. H. (2003). The Performance Implications of Ownership-Driven Governance Reform. European Management Journal, 21(6), 698-706. Retrieved from https://www.sciencedirect.com/science/article/pii/S0263237303001269

\section{Copyrights}

Copyright for this article is retained by the author(s), with first publication rights granted to the journal.

This is an open-access article distributed under the terms and conditions of the Creative Commons Attribution license (http://creativecommons.org/licenses/by/4.0/). 